\title{
DNA Methylation in Human Breast Cancer Cell Lines Adapted to High Nitric Oxide
}

\author{
BERNA DEMIRCAN ${ }^{1}$, BURCU YUCEL ${ }^{1}$ and JAMES A. RADOSEVICH ${ }^{2}$ \\ ${ }^{1}$ Department of Medical Biology, Medical School, Istanbul Medeniyet University, Istanbul, Turkey; \\ ${ }^{2}$ Oral Medicine and Diagnostic Sciences, College of Dentistry, University of Illinois, Chicago, IL, U.S.A.
}

\begin{abstract}
Background: Nitric oxide (NO) exposure has been suggested to cause alterations in DNA methylation in breast cancer. We investigated the effect of NO on DNA methylation of promoters in cell lines of breast cancer. Material and Methods: The methylation status of the promoters of breast cancer 1 (BRCA1), deleted in colon cancer (DCC), Rasassociation domain family $1 A$ (RASSF 1A), $O^{6}$-methylguanineDNA methyltransferase (MGMT), and secreted frizzled related protein 1 (SFRP1) were analyzed in the parental and high nitric oxide-adapted cell lines of breast cancer using Illumina MiSequencing. Results: Methylation of RASSF 1A promoter in BT-20-HNO (74.7\%) was significantly higher than that in BT-20 cells $(72 \%)(p<0.05)$, whereas in MCF-7HNO cells, methylation of MGMT promoter was found to have significantly decreased as compared to its parental cell line (45.1\% versus $50.1 \%$; $p<0.0001)$. Promoter methylation of SFRP and DCC was elevated in T-47D-HNO relative to its parent cell line $(p<0.05)$. Conclusion: Similarly to the double-edged effects of NO on tumorigenesis, its epigenetic effects through DNA methylation are diverse and contradictory in breast cancer.
\end{abstract}

Breast cancer is the most prevalent malignancy and second most common cause of cancer deaths among females (1-3). It affects approximately 1.5 million women worldwide each year (1). Patients with breast cancer with morphologically identical tumors exhibit different clinical courses. This may be the result of variations in the tumor microenvironment. It has been

This article is freely accessible online.

Correspondence to: Berna Demircan, Ph.D., Department of Medical Biology, Medical School, Istanbul Medeniyet University, 34000, Istanbul, Turkey. Tel: +90 2162802779, e-mail: berna.demircan@medeniyet.edu.tr

Key Words: DNA methylation, epigenetics, breast cancer, nitric oxide. proposed that the tumor microenvironment has a crucial role in tumor initiation as well as progression and metastasis. The free radical nitric oxide ( ${ }^{\circ} \mathrm{NO}$ ) is believed to be a factor at play in the tumor microenvironment (4-7). It has multiple effects on tumor biology. Depending on the dose and duration of exposure, NO exhibits its biological effects by either inhibiting or stimulating cell proliferation, migration and apoptosis (8). NO is reported to cause harm in the adipogenic environment of the breast, and thus initiates and promotes tumor development. Reactive oxygen species (ROS) and NO originating in the tumor microenvironment produce oxidative stress and inflammatory factors. Therefore, they change the microenvironment of the breast and create an environment for the transformation of breast cancer cells (9). NO is produced by nitric oxide synthase (NOS) which has three isoforms, neuronal, endothelial (eNOS) and inducible (iNOS) (5). Increased expression of NOS has been identified in human tumors including breast cancer $(4,5,8,9)$. iNOS is a proinflammatory enzyme involved in chronic inflammation. It has been shown that in patients with triple-negative breast tumors, iNOS expression is associated with worse prognosis and poor survival $(5,8,9)$.

Epigenetic mechanisms have appeared as essential players in the development and progression of breast cancer (1). DNA methylation is one of these mechanisms that regulate the differential expression of genes (10-12). It occurs at cytosines contained within cytosine-phosphate-guanine (CpG) dinucleotides. They are converted to 5-methylcytosine by incorporation of a methyl $\left(\mathrm{CH}_{3}\right)$ group to the fifth carbon of the pyrimidine ring of cytosine. DNA methyltransferases (DNMTs) are the main enzymes which regulate DNA methylation $(1,10)$. Abnormal DNA methylation of promoter $\mathrm{CpG}$ islands is often correlated with reduced transcriptional activity in cancer $(12,13)$.

Epigenetic silencing via promoter hypermethylation of more than 100 genes has been reported in breast cancer. These silenced genes are involved in cell-cycle regulation, DNA repair, tissue invasion, apoptosis and metastasis (1). Most of these mechanisms are also modulated by $\mathrm{NO}$ as 
explained above. This suggests that NO exposure might cause alterations in DNA methylation. NO has been already reported to be an epigenetic factor due to its impact on DNA methylation, microRNA and histone modification in normal as well as tumor tissues $(14,15)$. However, to our knowledge, the epigenetic effects of NO in terms of DNA methylation of promoters have never been investigated in breast cancer. To fully understand the influence of NO on DNA methylation in breast cancer, we utilized a model cell line system which was previously designed by our laboratory utilizing some of the breast cancer cell lines that were adapted to NO (16-23). These cells were progressively adapted to high concentrations of NO over a period of 2 months (4). At the end of the adaptation process, two significant results were obtained. Firstly, the untreated cell lines which we called 'parental' cells adapted to the high NO (HNO) level. Secondly, HNOadapted cell lines expanded more quickly and aggressively than each parental cell line. It was observed that HNOadapted cells continued to grow in the same way even when they were later grown without NO treatment $(4,5)$.

In this study, we investigated and compared the methylation status of promoter regions of breast cancer 1 (BRCAl), deleted in colon cancer $(D C C)$, Ras-association domain family $1 \mathrm{~A}(R A S S F 1 A), O^{6}$-methylguanine-DNA methyltransferase $(M G M T)$, and secreted frizzled related protein 1 (SFRP1) tumor-suppressor genes between parental breast cancer cell lines and their HNO-adapted derivatives.6

\section{Materials and Methods}

Cell lines and cell adaptation. Three human breast adenocarcinoma cell lines were utilized for this study: BT-20, MCF-7, and T-47D. These cell lines were obtained from the American Type Culture Collection (Manassas, VA, USA). T-47D was cultured in RPMI-1640 media. MCF-7 and BT-20 were each cultured in Minimum Essential Medium (MEM). How these three cell lineswere adapted to grow in comparatively high levels of NO has been reported (4). Briefly, the cell adaptation process was conducted over several months by exposing the parentaI cell lines to an NO donor, (Z)-1-[2-(2-aminoethyl)-N-(2amminoethyl) amino] diazen-1-ium-1,2-diolate (Sigma Life Sciences, St. Louis, MO, USA), at an initial concentration of $50 \mu \mathrm{M}$. The concentration was raised in increments of $25 \mu \mathrm{M}$ up to a point which was lethal to the parentaI cell line (a concentration of $600 \mu \mathrm{M}$ ) every few days. The newly adapted HNO cell lines were designated as BT20-HNO, MCF-7-HNO, and T-47D-HNO, respectively. Each media type was supplemented with $10 \%$ fetal calf serum (which was inactivated at $56^{\circ} \mathrm{C}$ for $30 \mathrm{~min}$ prior to use), $100 \mu \mathrm{g} / \mathrm{ml}$ streptomycin, $2 \mathrm{mM}$ L-glutamine, $2.5 \mu \mathrm{g} / \mathrm{ml}$ amphotericin B solution, and $100 \mathrm{U} / \mathrm{ml}$ penicillin. In addition, MEM was supplemented with $1 \mathrm{mM}$ sodium pyruvate and $100 \mathrm{mM}$ nonessential amino acids (CellGro, Inc. Manassas, VA, USA). All cell lines were maintained in a humidified incubator at $37^{\circ} \mathrm{C}$ and a concentration $\mathrm{CO}_{2}$ of $5 \%$.

Extraction and sodium bisulfite modification of genomic DNA. Genomic DNA was isolated from cultured human breast tumor cell lines by Qiagen Blood and Cell Culture DNA kit (Qiagen, Inc.,
Valencia, VA, USA) and stored at $-20^{\circ} \mathrm{C}$ before use. Isolated genomic DNA samples were treated with bisulfite deamination reaction using Qiagen EpiTect Bisulfite kit (Qiagen, Inc., Valencia, VA, USA) based on the manufacturer's instructions. Briefly, $500 \mathrm{ng}$ of DNA was used from each sample. The required amount of DNA was mixed with $85 \mu \mathrm{l}$ of bisulfite mix solution and $35 \mu \mathrm{l}$ of DNA preservation buffer in $200 \mu$ polymerase chain reaction (PCR) tubes. Samples were then incubated in a thermal cycler device (BioRad, Hercules, CA, USA) for 5 hours and in changing temperatures $\left(95^{\circ} \mathrm{C}\right.$ for $5 \mathrm{~min}, 60^{\circ} \mathrm{C}$ for $25 \mathrm{~min}, 95^{\circ} \mathrm{C}$ for $5 \mathrm{~min}$, $60^{\circ} \mathrm{C}$ for $85 \mathrm{~min}, 95^{\circ} \mathrm{C}$ for $5 \mathrm{~min}$, and $60^{\circ} \mathrm{C}$ for $175 \mathrm{~min}$, respectively). Samples were transferred to the Epitect spin columns (Qiagen, Inc., Valencia, VA, USA) after incubation, and desulfonation and washing buffers were added and centrifuged accordingly. Finally, bisulfite-treated DNA samples were purified in $20 \mu \mathrm{l}$ of elution buffer. One microliter of bisulfite-converted genomic DNA solution was used in subsequent PCR reactions.

PCR amplification and sequencing of BRCA1, DCC, RASSF1A, $M G M T, S F R P 1$. PCR reactions were performed using bisulfiteconverted genomic DNA using primers listed in Table I. PCR reactions were carried out via Qiagen HotStarTaq DNA polymerase and supplied 1X PCR buffer supplemented with $0.1 \mathrm{mmol} / 1 \mathrm{dNTPs}$, $2.5 \mathrm{mmol} / 1 \mathrm{MgCl}_{2}$, and $0.5 \mu \mathrm{mol} / \mathrm{l}$ each of forward and reverse primers and bisulfite-converted genomic DNA. The thermal cycler (BioRad, USA) was set up for initial activation step for $15 \mathrm{~min}$ at $95^{\circ} \mathrm{C}$, and followed by 45 cycling steps of $94^{\circ} \mathrm{C} 30 \mathrm{~s}$, optimized primer specific annealing temperature for $30 \mathrm{~s}$, and $72^{\circ} \mathrm{C} 30 \mathrm{~s}$. The PCR reaction was complete after the final elongation step applied at $72^{\circ} \mathrm{C}$ for $10 \mathrm{~min}$. Following amplification, the PCR products were loaded onto $10 \%$ polyacrylamide gels and visualized using ethidium bromide. Human placental genomic DNA (Biochain Institute, Hayward, CA, USA) was used as positive and negative control. This genomic DNA was either methylated in vitro with SssI methylase (NEB, Ipswich, MA, USA) or not methylated prior to bisulfite conversion as outlined previously (24). The PCR reactions were then analyzed by sequencing (control DNA was used for validation as described above).

Samples were then prepared for sequencing by ligation of barcoded sequencing adapters using a PrepX kit implemented on an Apollo 324 robotic system (IntegenX Inc., Pleasanton, CA, USA). Barcoded adapters were NEXTflex 6nt barcodes (Bio Scientific, Phoenix, AZ, USA). Sequencing was conducted on an Illumina MiSeq instrument (Illumina, San Diego, CA, USA) employing V3 chemistry (600 cycles). Library preparation and pooling of samples was performed by the University of Illinois at Chicago Sequencing Core Facility. Sequencing was carried out at the W.M. Keck Center for Comparative and Functional Genomics at the University of Illinois at Urbana-Champaign.

Raw sequence data were processed within the software package CLC genomics workbench (Qiagen, Redwood City, CA, USA). For each sample, from 450,303 to 827,542 clusters were acquired. Quality trimming (Q20, no ambiguous nucleotides allowed) was performed on all samples, and trimmed reads were mapped against reference 'converted' sequences for each gene (i.e. C positions were converted to T). Subsequently, variant calling was performed using the default CLC variant caller. Variant calling tables for each sample were exported, and for each nucleotide position, the number of sequences generating each base were counted. Wilcoxon matchedpairs signed-rank test was employed to compare the differences in 
Table I. Sequencing primers (amplification and sequencing).

\begin{tabular}{|c|c|c|c|c|c|c|}
\hline Gene name & Encoded protein & Primer sequence $\left(5^{\prime} \rightarrow 3^{\prime}\right)$ & Orientation & $\begin{array}{l}\text { Annealing } \\
\text { temp }\left({ }^{\circ} \mathrm{C}\right)\end{array}$ & $\begin{array}{l}\text { Thermo- } \\
\text { cycles }\end{array}$ & $\begin{array}{l}\text { Product } \\
\text { size (bp) }\end{array}$ \\
\hline \multirow[t]{3}{*}{ BRCA1 } & \multirow[t]{3}{*}{ Breast cancer 1} & GGGATAAGTGGTAAGAGTTAATTTTTTT & $\mathrm{F}$ & \multirow[t]{3}{*}{58} & \multirow[t]{3}{*}{45} & \multirow[t]{3}{*}{189} \\
\hline & & САССССТААСТААСССАААСТАСТ & $\mathrm{R}$ & & & \\
\hline & & GTGGTAAGAGTTAATTTTTTT & Seq* & & & \\
\hline \multirow[t]{3}{*}{$D C C$} & \multirow[t]{3}{*}{ Deleted in colon cancer } & GAAATTAATAGGGAATGGTATATTAAT & $\mathrm{F}$ & \multirow[t]{3}{*}{58} & \multirow[t]{3}{*}{45} & \multirow[t]{3}{*}{273} \\
\hline & & ТСТСТСТАТСТСТААССАААААААА & $\mathrm{R}$ & & & \\
\hline & & TAGGGAATGGTATATTAAT & Seq* & & & \\
\hline \multirow[t]{3}{*}{ RASSF1A } & \multirow{3}{*}{$\begin{array}{l}\text { Ras-association domain } \\
\text { family } 1 \mathrm{~A}\end{array}$} & GTAGTTTAATGAGTTTAGGTTTTTT & $\mathrm{F}$ & \multirow[t]{3}{*}{59} & \multirow[t]{3}{*}{45} & \multirow[t]{3}{*}{188} \\
\hline & & CTACACCCAAATTTCCATTAC & $\mathrm{R}$ & & & \\
\hline & & TAATGAGTTTAGGTTTTTT & Seq* & & & \\
\hline \multirow[t]{3}{*}{$M G M T$} & \multirow{3}{*}{$\begin{array}{c}\mathrm{O}^{6} \text {-Methylguanine-DNA } \\
\text { methyltransferase }\end{array}$} & GGTTTGGGGGTTTTTGATTAG & $\mathrm{F}$ & \multirow[t]{3}{*}{57.5} & \multirow[t]{3}{*}{45} & \multirow[t]{3}{*}{198} \\
\hline & & ССТТTТССТАТСАСАAАAАТАAТСC & $\mathrm{R}$ & & & \\
\hline & & GGGGGTTTTTGATTAG & Seq* & & & \\
\hline \multirow[t]{3}{*}{$S F R P 1$} & Secreted frizzled & GGGGAATTTGTTATATTTAAGTATTT & $\mathrm{F}$ & \multirow[t]{3}{*}{58} & \multirow[t]{3}{*}{45} & \multirow[t]{3}{*}{192} \\
\hline & related protein 1 & АТАССССТАСТСААСАААААСТАСС & $\mathrm{R}$ & & & \\
\hline & & TTGTTATATTTAAGTATTT & Seq* & & & \\
\hline
\end{tabular}

Seq*: Sequencing primer.

methylation between the parental and HNO-adapted cell lines, and Graphpad prism v6 (GraphPad Software, San Diego, CA, USA) program was used to conduct the statistical analysis.

\section{Results}

Comparison of promoter CpG methylation levels of BRCA1, DCC, RASSF1A, MGMT and SFRPI between the parental and HNO-adapted cell lines by Illumina Mi-Sequencing. The tumor-suppressor genes we studied (BRCAl, DCC, RASSF 1A, MGMT and SFRPI) have been shown to be epigenetically silenced to various extents by promoter DNA hypermethylation in breast cancer (25-30).

To perform PCR and sequencing analysis, we designed primers using an on-line primer design program (www.methprimer.org), which is publically available. The primer sets of PCR and MiSeq analysis were designed to determine DNA methylation levels near to the transcriptional start site of the tumor-suppressor genes because this region is most likely to be exposed to dense methylation during epigenetic silencing (31). By utilizing unmethylated and methylated human placental genomic DNA as negative and positive controls, respectively, we validated our results of sequencing analysis for the five genes (BRCAl, DCC, RASSF 1A, MGMT and SFRPI) studied in this report (Figure $1)$. Based on the sequencing protocol, the libraries from different samples were quantified and pooled together. After sequencing, the Illumina reads were post-processed and aligned to the human reference regions.

For all five genes, we detected promoter hypermethylation to various extents in the parental cell lines (BT-20, MCF-7, and T-47D) which was consistent with previous reports.
We first examined the sequencing results of $B R C A l$ by Illumina reads. The primers designed to amplify the $B R C A I$ gene sequence yielded a 189-bp amplicon and included 10 $\mathrm{CpG}$ dinucleotides. The results indicated that methylation of BRCAl did not significantly change in response to NO treatment in any of the cell lines (Figure 1).

A 188-bp segment from the CpG island of the RASSF1A promoter was amplified by PCR and used for MiSeq. Illumina MiSeq assay for the RASSF1A gene scores methylation of $16 \mathrm{CpG}$ dinucleotides within the amplified region of the $\mathrm{CpG}$ island within the 5' end of the gene. Based on the sequencing results, we observed that methylation level of RASSF $1 A$ in BT-20-HNO (74.7\%) cell was significantly $(p<0.05)$ higher than that of the parental line $(72 \%)$ but there was no difference between the other parentaI and HNOadapted cell lines.

MGMT was another tumor-suppressor gene whose promoter methylation status (198-bp segment including $21 \mathrm{CpG}$ ) which was analyzed by sequencing following PCR amplification. The MCF-7-HNO cell line (45.1\%) was found to have a significantly ( $\mathrm{p}<0.0001)$ reduced methylation of $M G M T$ as compared to its parental cell line $(50.1 \%)$. However, HNO-adapted BT-20 and T-47D cell lines had similar methylation levels when compared to their corresponding parental lines.

SFRP (192-bp segment with eighteen $\mathrm{CpG}$ ) sequencing results demonstrated that $S F R P$ methylation was elevated in the T-47D-HNO $(56.2 \%)$ cell line relative to its parental cell line $(55.0 \%)(p<0.05)$, while no significant change was observed between other cell lines.

Sequence analysis of DCC tumor-suppressor gene (273bp segment amplified with twenty $\mathrm{CpG}$ prior to MiSeq) 
A

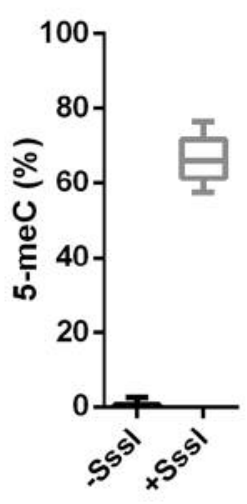

C

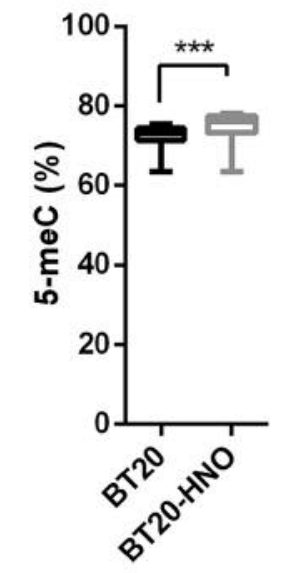

E

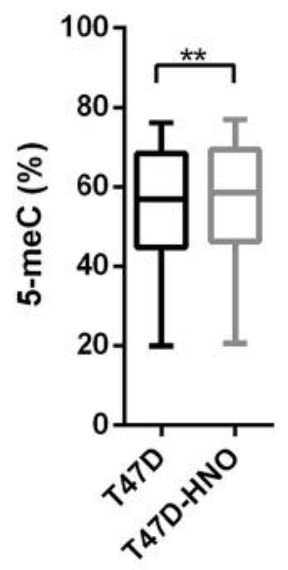

B

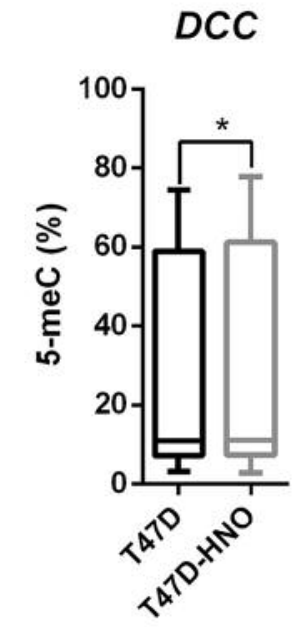

D

MGMT

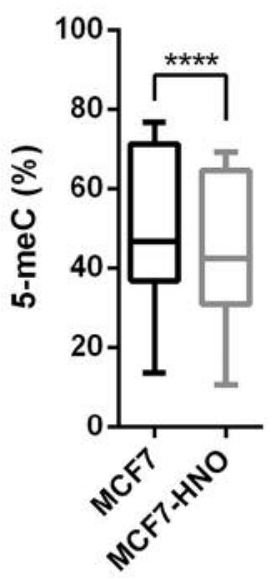

F

BRCA1

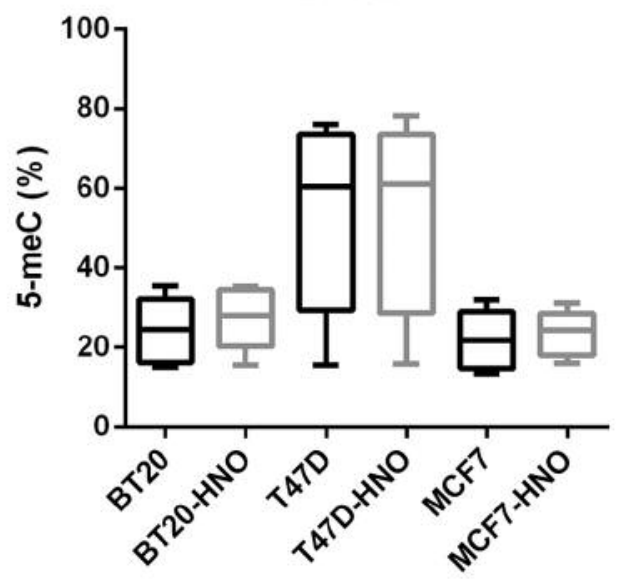

Figure 1. A: DNA methylation in control samples of placental DNA treated with SssI (+) and untreated (-). DNA methylation of promoters for genes in parentaI and high nitric oxide (HNO)-adapted cell lines: Deleted in colon cancer (DCC) in T47-D cells (B); Ras-association domain family 1A (RASSF1A) in BT20 cells (C); $O^{6}$-methylguanine-DNA methyltransferase (MGMT) in MCF7 cells (D); secreted frizzled related protein 1 (SFRP1) in T47-D cells (E); and breast cancer 1 (BRCA1) in BT-20, MCF-7 and T-47D cells (F). Data are presented as mean \pm standard deviation. Significantly different at: $* p<0.05, * * p<0.01$, ***p<0.001, and $* * * * p<0.0001$. 
showed that the level of methylation in T-47D-HNO (30.7\%) cells was significantly $(p<0.05)$ higher than in the parental cel line $(29.7 \%)$. No difference was detected between the parental and HNO cell line pairs for BT-20, and MCF-7 (Figure 1).

\section{Discussion}

NO is an unstable, reactive, free radical, and also an essential signal molecule in sustaining cellular homeostasis. It plays a critical role in physiological as well as pathological processes such as inflammation and cancer $(32,33)$. It has been shown that NO levels are higher in breast cancer as compared to that in benign breast epithelium $(8,9)$. Our previous studies characterized some molecular and cellular alterations induced by high NO concentration in human breast cancer using a model cell line system which was developed by our laboratory.

In order to make the role of NO clear epigenetically, we detected the level of methylation of a panel of five tumorsuppressor genes in the same model system of breast cancer cell lines in the current study. The tumor-suppressor genes BRCA1, DCC, RASSF 1A, MGMT and SFRPI were chosen since they have been shown to be subjected to epigenetic silencing by promoter hypermethylation in primary breast cancer (25-30). We used Illumina MiSequncing to quantify methylation of these genes in parental and HNO-adapted breast cancer cell lines and observed diverse results in response to NO treatment. Placental gDNA sequencing acted as our negative and positive controls (-SssI and $+S S S I$ ) (Figure 1).

$B R C A 1$ is a classic tumor-suppressor gene and is associated with the regulation of gene transcription, DNA repair, apoptosis, cell-cycle checkpoint control and remodeling of chromosomes $(34,35)$. Inherited germline mutations in BRCA1 result in the formation of aggressive breast tumors. In addition, it has been reported that DNA methylation was the major cause of $B R C A l$ gene silencing, ranging from $10-30 \%$ in sporadic breast cancer (36-39). Our findings on BRCA1 promoter methylation of BT-20, MCF-7, and T-47D were consistent with previous studies. However, treatment of these cell lines with NO did not significantly change the level of methylation of BRCAI gene promoter (Figure 1).

RASSF $1 A$ is involved in microtubule stability, cell-cycle progression and apoptosis (40). Promoter hypermethylation of RASSF 1A has been observed in breast cancer in recent studies (41-44). We found a significantly elevated level of methylation of RASSF1A promoter only in the BT-20-derived cell line out of four HNO-adapted breast cancer cell lines. In penwork from our laboratory, it was observed that iNOS and eNOS expression was significantly up-regulated in BT-20 HNO cells compared to the parental cell line (5), which was in agreement with the literature reporting the link of high NOS expression and NO levels with breast cancer $(8,9)$.

We subsequently demonstrated the relationship between promoter methylation levels of DCC and SFRPI genes in the T47D cell line and high NO concentrations. SFRPI is a member of the frizzle protein family and negatively regulates the Wnt signalling pathway (45-47). DCC is involved in cell progression, migration and adhesion (48). Both SFRPI (30) and $D C C$ (29) have been shown to be epigenetically silenced by DNA hypermethylation in breast cancer. In the current study, these genes had significantly higher levels of methylation in T47D-HNO cells than in the parental cell line. Unlike up-regulation of iNOS and eNOS expression in BT-20-HNO cells as stated above, expression of both isoforms in T-47D-HNO cells was reduced compared to the parental cell line (5).

Another tumor-suppressor gene we studied was MGMT, which functions in DNA repair (49), and whose aberrant promoter hypermethylation has been shown in one-third of breast cancer cases (28). Contrary to the elevatin of methylation of RASSF $1 A, S F R P 1$ and DCC promoter in at least one HNO-adapted breast cancer cell line, we observed that methylation of $M G M T$ promoter was significantly reduced in MCF-7-HNO cells compared to the parentaI cell line. Western blot analysis demonstrated that iNOS expression was also lower in MCF-7-HNO cells than the parentaI cells, while eNOS expression was higher (5).

Taken together, our findings suggest that much like the double-edged effects of NO on tumorigenesis, its epigenetic impacts through DNA methylation are diverse and contradictory. To the best of our knowledge, there are no reports about the effects of $\mathrm{NO}$ on promoter DNA methylation in breast cancer. However, studies performed in various types of cancer and diseases in order to understand the epigenetic role of NO have yielded conflicting results. While some reported that NO induced a global decrease in methylcytosine, others found $\mathrm{CpG}$ hypermethylation and subsequent transcriptional silencing. For example, Hmadcha et al. observed that direct application of NO donors to several cell types induced promoter methylation of fragile $\mathrm{X}$ mental retardation gene $(F M R l)$, which led to the suppression of the expression of this gene (50). Another study using a murine squamous cell carcinoma model demonstrated that NO overexpression resulted in a global decrease in DNA methyltransferase 1 (DNMT1) and DNMT3a activity, and in 5-methylcytosine level (51).

Huang et al. showed that treatment of gastric cancer cells with Helicobacler pylori stimulated an increase in NO level, DNMT activity and DNA methylation (52). In addition, Huang et al. (52) and Katayama et al. (53) found that NO induced promoter DNA methylation of E-cadherin and Runtrelated transcription factor 3 (RUNX3) respectively, in gastric cancer. 
The findings outlined above suggest that it is difficult to establish a direct connection between NO and DNA methylation. New approaches toward understanding the influence of NO on epigenetic mechanisms, including the interactions of $\mathrm{NO}$ with iron and its effect in the modulation of iron homeostasis, have been proposed by some researchers. Cellular iron is essential for the activity of a wide range of diverse enzymes (54). A number of epigenetic-regulatory enzymes are iron-dependent, such as histone demethylases, which NO inhibits by binding to the catalytic iron $(55,56)$. Another iron-dependent epigenetic regulatory enzyme is ten-eleven translocation (TET) which catalyzes DNA demethylation in a process that removes or modifies the methyl group from 5-methylcytosine. TET enzyme uses iron, $\alpha$-ketoglutarate and oxygen to convert 5methylcytosine to 5-hydroxymethylcytosine, which is associated with active gene transcription (55-57). It has been proposed that inhibition of TET activity by NO might alter the expression of specific genes due to the accumulation of 5-methylcytosine in the genome $(55,56)$. Thus, NO might result in epigenetic silencing of spesific tumor-suppressor genes by inducing DNA hypermethylation.

NO has three sources in the body, namely dietary, pharmacological and endogenous enzymatic synthesis. However, which sources of NO are more susceptible to epigenetic regulation is unknown (10). For this reason, future investigations to reveal epigenetic effects of NO should take into consideration this point.

In conclusion, NO-induced epigenetic modifications may positively or negatively regulate gene expression. As most epigenetic modifications are reversible, targeting NO might restore epigenetic modifications in tumorigenesis, hence proving to be an efficient therapeutic strategy. Further studies are needed to completely elucidate NO-induced epigenetic mechanisms and develop new epigenetic treatment options in breast cancer.

\section{Conflicts of Interest}

The Authors declare no conflict of interest in regard to this study.

\section{Authors' Contributions}

BD and JAR designed the project and experiments. BD performed cell adaptation process, DNA extraction, bisulfite modification, PCR and sequencing analysis. BY performed data analysis and statisitcal analysis. BD and JAR wrote/revised the article. All Authors read and approved the final article.

\section{Acknowledgements}

This investigation was supported by the VA Merit Review Grant, USA.

\section{References}

1 Pasculli B, Barbano R and Parrella P: Epigenetics of breast cancer: Biology and clinical implication in the era of precision medicine. Semin Cancer Biol 51: 22-35, 2018. PMID: 31212911. DOI: $10.3390 / \mathrm{ijms} 20122949$

2 Ouyang FS, Guo BL, Huang XY, Ouyang LZ, Zhou CR, Zhang R, Wu ML, Yang ZS, Wu SK, Guo TD, Yang SM and Hu QG: A nomogram for individual prediction of vascular invasion in primary breast cancer. Eur J Radiol 110: 30-38, 2019. PMID: 30599870. DOI: 10.1016/j.ejrad.2018.11.013

3 Xin M, Wang Y, Ren Q and Guo Y: Formononetin and metformin act synergistically to inhibit growth of MCF-7 breast cancer cells in vitro. Biomed Pharmacother 109: 2084-2089, 2019. PMID: 30551465. DOI: 10.1016/j.biopha.2018.09.033

4 Vesper B, Elseth KM, Tarjan G, Haines GK and Radosevich J: Long-term adaptation of breast tumor cell lines to high concentrations of nitric oxide. Tumor Biol 31: 267-275, 2010. PMID: 20480412. DOI: 10.1007/s13277-010-0028-6

5 Vesper B, Onul A, Haines GK, Tarjan G, Xue J, Elseth KM, Aydogan B, Altman MB, Roeske JC, Paradise WA, De Vitto H and Radosevich JA: Molecular and cellular characterization of high nitric oxide-adapted human breast adenocarcinoma cell lines. Tumor Biol 34: 203-214, 2013. PMID: 23238815. DOI: 10.1007/s13277-012-0530-0

6 Somasundaram V, Basudhar D, Bharadwaj G No JH, Ridnour LA, Cheng RYS, Fujita M, Thomas DD, Anderson SK, McVicar DW and Wink DA: Molecular mechanisms of nitric oxide in cancer progression, signal transduction, and metabolism. Antioxid Redox Signal 30(8): 1124-1143, 2019. PMID: 29634348. DOI: $10.1089 /$ ars.2018.7527

7 Qu X, Tang Y and Hua S: Immunological approaches towards cancer and inflammation: A cross talk. Front Immunol 20: 563, 2018. PMID: 29662489. DOI: 10.3389/fimmu.2018.00563

8 Garrido P, Shalaby A, Walsh EM, Keane N, Webber M, Keane MM, Sullivan FJ, Kerin MJ, Callagy G, Ryan AE and Glynn SA: Impact of inducible nitric oxide synthase (iNOS) expression on triple-negative breast cancer outcome and activation of EGFR and ERK signaling pathways. Oncotarget 8: 80568-80588, 2017. PMID: 29113326. DOI: 10.18632/oncotarget.19631

9 Wen HC, Chuu CP, Chen CY, Shiah SG, Kung HJ, King KL, Su LC, Chang SC and Chang CH: Elevation of soluble guanylate cyclase suppresses proliferation and survival of human breast cancer cell. PLoS One 10: 1-17, 2015. PMID: 25928539. DOI: 10.1371/journal.pone. 0125518

10 Socco S, Bovee RC, Palczewski MB, Hickok JR and Thomas DD: Epigenetics: The third pillar of nitric oxide signaling. Pharmacol Res 121: 52-58, 2017. PMID: 28428114. DOI: 10.1016/j.phrs.2017.04.011

11 Holliday H, Baker LA, Junankar SR, Clark SJ and Swarbrick A: Epigenomics of mammary gland development. Breast Cancer Res 20: 100, 2018. PMID: 30176939. DOI: 10.1186/s13058-018-1031-x

12 eong YJ, Oh HK, Park SH and Bong JG: Prognostic significance of activated leukocyte cell adhesion molecule (ALCAM) in association with promoter methylation of the ALCAM gene in breast cancer. Molecules 23: E131, 2018. PMID: 29315254. DOI: 10.3390/molecules23010131

13 Tsai HC and Baylin S: Cancer Epigenetics: Linking basic biology to clinical medicine. Cell Res 21: 502-517, 2011. PMID: 21321605. DOI: $10.1038 /$ cr.2011.24 
14 Nott A and Riccio A: Nitric oxide-mediated epigenetic mechanisms in developing neurons. Cell Cycle 8: 725-730, 2009. PMID: 19221483. DOI: $10.4161 / \mathrm{cc} .8 .5 .7805$

15 Hickok JR, Vasudevan D, Antholine WE and Thomas DD: Nitric oxide modifies global histone methylation by inhibiting Jumonji C domain-containing demethylases. J Biol Chem 288: 1600415, 2013. PMID: 23546878. DOI: $10.1074 /$ jbc.M112.432294

16 Bentz BG, Simmons RL, Haines III GK and Radosevich JA: The Yin and Yang of nitric oxide. Reflections on the physiology and pathophysiology of NO. Head Neck 22: 71-83, 2000. PMID: 10585608 .

17 Bentz BG, Hammer ND, Milash B, Klein S, Burnett DM, Radosevich JA and Haines GK: Nitric oxide's kineteics and redox state determine the biological consequences in lung adenocarcinoma. Tumor Biol 28: 301-311, 2007. PMID: 18253068. DOI: $10.1159 / 000115526$

18 Paradise WA, Vesper BJ, Goel A, Waltonen JD, Altman KW, Haines GK and Radosevich JA: Nitric oxide: Perspectives and emerging studies of a well-known cytotoxin. Inter J Mol Sci 11: 2715-2745, 2010. PMID: 20717533. DOI: 10.3390/ijms 11072715

19 De Vitto H, Mendonca BS, Elseth KM, Onul A Xue J, Vesper BJ, Gallo CV, Rumjanek FD, Paradise WA and Radosevich JA: Part III. Molecular changes induced by high nitric oxide adaptation in human breast cancer cell line BT-20 (BT-20-HNO): A switch from aerobic to anaerobic metabolism. Tumor Biol 34: 403-413, 2013 PMID: 23238817. DOI: 10.1007/s13277-012-0564-3

20 De Vitto H, Mendonca BS, Elseth KM, Vesper BJ Portari EA, Gallo CV, Paradise WA, Rumjanek FD and Radosevich JA: Part II. Mitochondrial mutational status of high nitric oxide-adapted cell line BT-20 (BT-20-HNO) as it relates to human primary breast tumors. Tumor Biol 34: 337-347, 2013. PMID: 23238816. DOI: $10.1007 / \mathrm{s} 13277-012-0555-4$

21 Aqil, M, Deliu Z, Elseth KM, Shen G, Xue J and Radosevich JA: Part II - mechanism of adaptation: A549 cells adapt to high concentration of nitric oxide through bypass of cell cycle checkpoints. Tumor Biol 35: 2417-2425, 2014. PMID: 24241959. DOI: $10.1007 / \mathrm{s} 13277-013-1319-5$

22 Aqil M, Elseth K, Vesper BJ, Aydogan B, Xue J and Radosevich JA: Part I - mechanism of adaptation: high nitric oxide adapted A549 cells show enhanced DNA damage response and activation of antiapoptic pathways. Tumor Biol 35: 2403-2415, 2014. PMID: 24241898. DOI: 10.1007/s13277-013-1318-6

23 Deliu Z, Tamas T, Aqil M, Bassiony M and Radosevich JA: Expression of cross-tolerance to a wide range of conditions in a human lung cancer cell line after adaptation to nitric oxide. Tumor Biol 1: 1-10, 2017. PMID: 28936924. DOI: $10.1177 / 1010428317723778$

24 Vo QN, Kim WJ, Cvitanovic L, Boudreau DA, Ginzinger DG and Brown KD: The ATM gene is a target for epigenetic silencing in locally advanced breast cancer. Oncogene 23: 9432 9437, 2014. PMID: 15516988. DOI: 10.1038/sj.onc.1208092

25 Imanishi S, Naoi Y, Shimazu K, Shimoda M, Kagara N, Tanei T, Miyake T, Kim SJ and Noguchi S: Clinicopathological analysis of homologous recombination-deficient breast cancers with special reference to response to neoadjuvant paclitaxel followed by FEC. Breast Cancer Res Treat 174: 627-637, 2019. PMID: 30607631. DOI: 10.1007/s10549-018-05120-9

26 Salta S, Nunes SP, Fontes-Sousa M, Lopes P, Freitas M, Caldas M, Antunes L, Castro F, Antunes P, Palma de Sousa S, Henrique
R and Jerónimo C: A DNA methylation-based test for breast cancer detection in circulating cell-free DNA. J Clin Med 7: E420, 2018. PMID: 30405052. DOI: 10.3390/jcm7110420

27 Karsli-Ceppioglu S, Dagdemir A, Judes G, Ngollo M, PenaultLIorca F, Pajon A, Bignon YJ and Bernard-Gallon D: Epigenetic mechanisms of breast cancer: An update of the current knowledge. Epigenomics 6: 651-664, 2014. PMID: 25531258. DOI: $10.2217 /$ epi.14.59

28 An N, Shi Y, Ye P, Pan Z and Long X: Association between MGMT promoter methylation and breast cancer: A metaanalysis. Cell Physiol Biochem 42: 2430-2440, 2017. PMID: 28848211. DOI: 10.1159/000480196

29 Miyamoto K, Fukutomi T, Akashi-Tanaka S, Hasegawa T, Asahara $\mathrm{T}$, Sugimura $\mathrm{T}$ and Ushijima T: Identification of 20 genes aberrantly methylated in human breast cancers. Int J Cancer 116: 407-414, 2005. PMID: 15818620. DOI: 10.1002/ijc.21054

30 Sturgeon SR, Balasubramanian R, Schairer C, Muss HB, Ziegler $\mathrm{RG}$ and Arcaro KF: Detection of promoter methylation of tumor suppressor genes in serum DNA of breast cancer cases and benign breast disease controls. Epigenetics 7: 1258-1267, 2012. PMID: 22986510. DOI: 10.4161/epi.22220

31 Jones PA and Baylin SB: The fundamental role of epigenetic events in cancer. Nat Rev Genet 3: 415-428, 2002. PMID: 12042769. DOI: $10.1038 / \operatorname{nrg} 816$

32 Lala PK and Orucevic A: Role of nitric oxide in tumor progression: Lessons from experimental tumors. Cancer Metastasis Rev 17: 91-106, 1998. PMID: 9544425.

33 Vasudevan D, Bovee RC and Thomas DD: Nitric oxide, the new architect of epigenetic landscapes. Nitric Oxide 59: 54-62, 2016. PMID: 27553128. DOI: 10.1016/j.niox.2016.08.002

$34 \mathrm{Wu}$ L, Shen Y, Peng X, Zhang S, Wang M, Xu G, Zheng X, Wang $\mathrm{J}$ and Lu C: Aberrant promoter methylation of cancerrelated genes in human breast cancer. Oncol Lett 12: 5145-5155, 2016. PMID: 28105221. DOI: 10.3892/ol.2016.5351

35 Wendt $\mathrm{C}$ and Margolin S: Identifying breast cancer susceptibility genes - a review of the genetic background in familial breast cancer. Acta Oncol 3: 1-12, 2019. PMID: 30606073. DOI: 10.1080/0284186X.2018.1529428

36 Wei M, Grushko TA, Dignam J, Hagos F, Nanda R, Sveen L, Xu J, Fackenthal J, Tretiakova M, Das S and Olopade OI: BRCA1 promoter methylation in sporadic breast cancer is associated with reduced BRCAl copy number and chromosome 17 aneusomy. Cancer Res 65: 10692-10699, 2005. PMID: 16322213. DOI: 10.1158/0008-5472.CAN-05-1277

37 Matros E, Wang ZC, Lodeiro G, Miron A, Iglehart JD and Richardson AL: BRCA1 promoter methylation in sporadic breast tumors: relationship to gene expression profiles. Breast Cancer Res Treat 91: 179-186, 2005. PMID: 15868446. DOI: 10.1007/s10549004-7603-8

38 Dobrovic A and Simpfendorfer D: Methylation of the BRCA1 gene in sporadic breast cancer. Cancer Res 57: 3347-3350, 1997. PMID: 9269993.

39 Rice JC, Ozcelik H, Maxeiner P, Andrulis I and Futscher BW: Methylation of the BRCA1 promoter is associated with decreased BRCA1 mRNA levels in clinical breast cancer specimens. Carcinogenesis 21: 1761-1765, 2000. PMID: 10964110. DOI: $10.1093 / \mathrm{carcin} / 21.9 .1761$

40 Tserga A, Michalopoulos NV, Levidou G, Korkolopoulou P, Zografos G, Patsouris E and Saetta AA: Association of aberrant DNA methylation with clinicopathological features in breast 
cancer. Oncol Rep 27: 1630-1638, 2012. PMID: 22159596. DOI 10.3892/or.2011.1576

41 Alvarez C, Tapia T, Cornejo V, Fernandez W, Muñoz A, Camus M, Alvarez M, Devoto L and Carvallo P: Silencing of tumorsuppressor genes RASSF1A, SLIT2, and WIF1 by promoter hypermethylation in hereditary breast cancer. Mol Carcinog 52: 475-487, 2013. PMID: 22315090. DOI: $10.1002 / \mathrm{mc} .21881$

42 Kajabova V, Smolkova B, Zmetakova I, Sebova K, Krivulcik T, Bella V, Kajo K, Machalekova K and Fridrichova I: RASSF1A promoter methylation levels positively correlate with estrogen receptor expression in breast cancer patients. Transl Oncol 6 : 297-304, 2013. PMID: 23730409. DOI: 10.1593/tlo.13244

$43 \mathrm{Li} \mathrm{Y}$, Wei Q, Cao F and Cao X: Expression and promoter methylation of the RASSF 1A gene in sporadic breast cancers in Chinese women. Oncol Rep 19: 1149-1153, 2008. PMID: 18425370

$44 \mathrm{Xu} \mathrm{J}$, Shetty PB, Feng W, Chenault C, Bast RC Jr, Issa JP, Hilsenbeck SG and Yu Y: Methylation of HIN-1, RASSF 1A, RIL and $\mathrm{CDH} 13$ in breast cancer is associated with clinical characteristics, but only RASSF $1 A$ methylation is associated with outcome. BMC Cancer 12: 243, 2012. PMID: 22695491. DOI: 10.1186/1471-2407-12-243

45 Peng JX, Liang SY and Li L: SFRP1 exerts effects on gastric cancer cells through GSK3 $\beta /$ RAC1-mediated restraint of TGF $\beta$ /SMAD3 signaling. Oncol Rep 41: 224-234, 2019. PMID: 30542739. DOI: $10.3892 /$ or.2018.6838

46 Wang Z, Ye Y, Liu D, Yang X and Wang F: Hypermethylation of multiple Wnt antagonist genes in gastric neoplasia: Is $H$. pylori infection blasting fuse? Medicine 97: e13734, 2018 PMID: 30593147. DOI: 10.1097/MD.0000000000013734

47 Mo S, Su Z, Heng B, Chen W, Shi L, Du X and Lai C: SFRP1 promoter methylation and renal carcinoma risk: A systematic review and meta-analysis. J Nippon Med Sch 85: 78-86, 2018. PMID: 29731501. DOI: 10.1272/jnms.2018 85-13

48 Liu X, Wang X, Fu SW, Wang M, Kang H, Guan H, Zhang S, Ma X, Lin S, Liu K, Feng Y, Dai C and Dai Z: Genetic association of deleted in colorectal carcinoma variants with breast cancer risk: A case-control study. Oncotarget 7: 3276532773, 2016. PMID: 27127179. DOI: 10.18632/oncotarget.9024

49 Bobustuc GC, Kassam AB, Rovin RA, Jeudy S, Smith JS, Isley B, Singh M, Paranjpe A, Srivenugopal KS and Konduri SD: $M G M T$ inhibition in ER-positive breast cancer leads to CDC2, TOP2A, AURKB, CDC20, KIF20A, Cyclin A2, Cyclin B2, Cyclin D1, ER $\alpha$ and survivin inhibition and enhances response to temozolomide. Oncotarget 9: 29727-29742, 2018. PMID: 30038716. DOI: 10.18632 /oncotarget.25696
50 Hmadcha A, Bedoya FJ, Sobrino F and Pintado E: Methylationdependent gene silencing induced by interleukin $1 \beta$ via nitric oxide production. J Exp Med 190: 1595-1603, 1999. PMID: 10587350. DOI: $10.1084 /$ jem.190.11.1595

51 Zhao H, Ning S, Scicinski J, Oronsky B, Knox SJ and Peehl DM: Epigenetic effects of RRx-001: A possible unifying mechanism of anticancer activity. Oncotarget 6: 43172-43181, 2015. PMID: 26657731. DOI: 10.18632/oncotarget.6526

52 Huang FY, Chan AO, Rashid A, Wong DK, Cho CH and Yuen MF: Helicobacter pylori induces promoter methylation of Ecadherin via interleukin- $1 \beta$ activation of nitric oxide production in gastric cancer cells. Cancer 118: 4969-4980, 2012. PMID: 22415887. DOI: $10.1002 /$ cncr.27519

53 Katayama Y, Takahashi M and Kuwayama H: Helicobacter pylori causes RUNX3 gene methylation and its loss of expression in gastric epithelial cells, which is mediated by nitric oxide produced by macrophages. Biochem Biophys Res Commun 388: 496-500, 2009. PMID: 19665002. DOI: 10.1016/j.bbrc. 2009.08.003

$54 \mathrm{Cyr}$ AR and Domann FE: The redox basis of epigenetic modifications: From mechanisms to functional consequences. Antioxid Redox Signal 15: 551-589, 2011. PMID: 20919933. DOI: 10.1089 /ars.2010.3492

55 Branco MR, Ficz G and Reik W: Uncovering the role of 5hydroxymethylcytosine in the epigenome. Nat Rev Genet 13: 713, 2011. PMID: 22083101. DOI: $10.1038 / \mathrm{nrg} 3080$

56 Kohli RM and Zhang Y: TET enzymes, TDG and the dynamics of DNA demethylation. Nature 502: 472-479, 2013. PMID: 24153300. DOI: $10.1038 /$ nature 12750

57 Yang H, Liu Y, Bai F, Zhang JY, Ma SH, Liu J, Xu ZD, Zhu HG, Ling ZQ, Ye D, Guan KL and Xiong Y: Tumor development is associated with decrease of TET gene expression and 5methylcytosine hydroxylation. Oncogene 32: 663-669, 2013. PMID: 22391558. DOI: 10.1038/onc.2012.67 